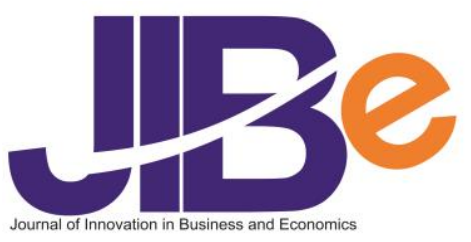

\title{
Efficacy of Social Accounting Practices on the Financial Performance: Evidence from Ethiopia
}

Uvaneswaran S M${ }^{1}$, Tsega Zemen ${ }^{2}$, Seid Muhammed ${ }^{3}$

College of Business and Economics, Wollo Univesity, Dessie, Ethiopia ${ }^{1,2,3}$

\begin{abstract}
This aims of this paper is to examine the effects of social accounting practices on the financial performance of business organizations in the city of Dessie, South Wollo, Ethiopia. To fulfill this objective, a stratified-random sampling design was used, followed by proportional sampling techniques. The research data were obtained from primary and secondary sources and analyzed using multiple linear regression to understand the effect of corporate social responsibility accounting practices on financial performance. The results of the study indicated that report on social accounting was indeed necessary, however, there was no standard guideline followed when reporting except the Ethiopian commercial code and statement of socio-economic operations. Likewise, the observation during this research showed that an increase in corporate social responsibility scores would lead to an increase in the company's financial performance.
\end{abstract}

Keywords: Corporate social responsibility; social accounting; financial performance

\section{Introduction}

Social accounting is a branch of accounting which attempts to measure the social benefits that an organization provides and the social costs that an organization incurs, with a view of using such to make available information that would enhance appropriate allocation of scarce resources for the benefit of the organization and the society (Huang \& Watson, 2015). Crowther (2000) considers social accounting as an approach for reporting the firm's activities that stresses the need for identification of socially relevant behavior and its social performance by the development of appropriate measures and reporting techniques. Social accounting and reporting is part of Corporate Social Responsibility (CSR) that organizations can use to gain competitive advantage over the firms and those who fails to practice it then the firms would be difficult to link the corporate social responsibility and competitive advantage (McWilliams \& Siegel, 2011; Saeidi, \& Saaeidi, 2015). Society is seen to benefit when organizations implement a social approach to accounting and reporting in a number of ways; honoring stakeholders right of information, balancing corporate power with corporate responsibility, increasing transparency of corporate activity, identifying social and environmental costs of economic success (Gray, 2000).

On the other hand, organization will benefit from applying social accounting practices in the following ways; increasing information for decision making, establishing more accurate product or service costs, improving image and public relations management, identifying social responsibility, identifying market development opportunities and maintaining legitimacy. An accountable business performance reporting process to stakeholders helps in integrating these performs into business practices and also for identifying future risks and opportunities. Furthermore, the firms can disclose their social activities in the annual statements stating the positive activities in limited manner. They also use other channels of communicating such as newspapers and the company websites (Kalunda, 2007).

This paper would try to establish the nature and mode of social accounting practices among the Ethiopian firms located in Dessie Town according to the list of Ethiopian chamber of commerce. The sectoral association and the ministry of trade whether the firms engaging in corporate social responsibility practices has any impact on their financial performance. Chepkoech, Chenuos, \& Kosgei (2015) stated that the performance is a general term applied to a part or to all the conducts of activities of an organization over a period of time often with reference to past or projected cost efficiency, management responsibility

${ }^{1}$ E-mail: uvaneshsm@gmail.com

2E-mail: tsegazemen@gmail.com

${ }^{3}$ E-mail: seidmuhammedahmed@gmail.com 
or accountability or the like. Financial Performance is defined as the process of measuring the results of a firm's policies and operations in monetary terms. It is used to measure firm's overall financial health over a given period of time and can also be used to compare similar firms across the same industry or to compare industries or sectors in aggregation.

Presently, the demand for transparency and accountability of social accounting disclosure and reporting is increasing and also desirable by products of economic activities (Kalunda, 2007). Apart from these, the active consumer groups, the public and the government departments demand it and in future, legislations promoted by these groups may make it mandatory. According to Iyoha (2010), society needs social accounting reports by the government, creditors and investors about financial information supplied by financial accounting systems. Users of social accounting information need the data that allow them to assess whether the entity is being socially, financially and environmentally responsible.

However, even though social accounting and reporting are new phenomena at a time when there is a lack of mandatory regulations for disclosure in Ethiopia, companies voluntarily engage in reporting some social responsibility activities in their annual financial reports and it seems that the company has developed far more than the literature. In addition, large and medium-sized companies located in Dessie are more involved in different sectors and the contribution to corporate social responsibility is limited or not limited to be identified and also the application of social accounting practices. A lot of research has been done on corporate social responsibility in general and on accounting and social reporting, but no one has focused on its effect on the company's financial performance. This study aimed at determining the methods of social accounting practices and reporting guidelines referred to by organizations and also examine whether social accounting practices have an effect on the company's financial performance as measured by Return on Assets.

\section{Literature Review}

A series of studies carried out have shown that corporate social reporting by companies is increasing (Deegan et al., 1996). Maunders (1982) carried out a survey of published accounts of 300 large companies for the period 1981 to 1982 and concluded that the largest incidence of voluntary disclosure was in the area of human resource. Gray et al. (1995) concluded that for the various categories of social disclosures which included environmental, community and safety the average amount of disclosure had steadily increased from the year 1979 to the year 1991. Cochran (1984) used the corporate social responsibility rankings to test the relationship between corporate social responsibility activities and a firm's performance. After controlling for industry classification and corporate age, a weak, positive association between social responsibility activities and financial performance was found. Mills (1984) concluded in his analysis of the relationship between social disclosure and financial performance that companies were more likely to disclose social responsibility expenditures when their financial statements indicated favorable financial performance.

Jerotich (2013) carried out a research to establish the relationship between corporate social responsibility and financial performance of firms in the Manufacturing, Construction and Allied Sector of the Nairobi Securities. One major finding of the study was that there was a strong relationship between the independent variables (CSR practice, efficiency and capital intensity) used in the model and the dependent variable (ROA). Meanwhile, Karthikeyan (2013) in a study about Social Statement Approach to Cooperative Social Performance Assessment: A Case of Lume Adama Farmers Cooperative Union in Ethiopia, revealed that cooperatives were engaged not only in doing business but also rendering social services. They prepared social income statement, which contained social benefits and costs to members, employees, community and the government and also prepared social balance sheet to show the position of social assets and liabilities. It was found that cooperatives used social statement approach to show the social performance of the union which consisted of social income statement and social balance sheet. The social statements showed that the cooperative union was engaging more in social projects like hospitals bakery unit for employment creation, school for stakeholders' children, and other welfare activities, which resulted in net social benefits to stakeholders (Du, Bhattacharya, \& Sen, 2010; Torres, Bijmolt, Tribó, \& Verhoef, 2012).

According to Margolis et al. (2002), one hundred twenty-two published studies between 1971 and 2001 empirically examined the relationship between corporate Social responsibility and financial performance. The first study was published by Narver in 1971. Empirical studies of the relationship between corporate social responsibility and financial performance comprise essentially two types. The first used the event study methodology to assess the Short-run financial impact (abnormal returns) when firms engage in either socially responsible or irresponsible acts. The results of these studies have been mixed. The second type of study examined the relationship between some measures of corporate social 
performance and measures of long term financial performance, by using accounting or financial measures of profitability. The studies that explored the relationship between social responsibility and accountingbased performance measures were shown as mixed results.

Okeyo (2004) carried out a study on the rationale and factors that determined the levels of corporate social responsibility among firms in Kenya. The research was carried out about 1997 to 2001 using questionnaire. A sample of eighty three firms was chosen out of which fifty nine responded. Correlation analysis was used to analyze the data. The research found out those firms in Kenya exhibited high levels of involvement in corporate social responsibility. This high level of involvement was mainly driven by the use of corporate social responsibility as a long term strategy. In conclusion, the average profitability, industry sector and management style were found to be the factors that determined levels of corporate social responsibility involvement among Kenyan firms. Oduol (2009) surveyed the social accounting and reporting practices adopted by the mobile phone service providers in Kenya. The population of the study covered four mobile firms that were operating in Kenya by the year 2009. The study used both primary and secondary data. Primary data was collected by way of questionnaires. Content analysis method was used in analyzing the data via statistical package for social sciences software. The study found that all companies in the mobile phone services industry participated in social responsibility activities and had positive performance in the business operations.

Thus it can be concluded that much research has been carried out based on the belief that responsible companies are valued by their good reputation. As a result, some studies have a positive correlation, others are negative and or have no correlation at all. Furthermore, those studies were also conducted to find out about the contribution of corporate social responsibility activities and social accounting practices in cooperative communities in Ethiopia but did not explore the application of this concept to companies in Ethiopia. From the summary above, it is known that the researchers have not been conclusive regarding how Ethiopian companies report their social and environmental activities in their financial statements. Therefore, this study aims to bridge the gap because the companies selected in Dessie include social costs in annual financial reports that have an impact on financial performance.

\section{Research Method}

This study was conducted using a correlational descriptive survey design, employing secondary quantitative data. The target population in this research was limited to business organizations in Dessie town, Ethiopia. Further, the Ethiopian Income tax proclamation No.286/2002 specifies that business organizations that earn annual turnover of more than Br. 100,000 are required to keep books of accounts. Although there are various categories of taxpayers in Ethiopia, this study targeted the class "A" taxpayer category found in the Dessie Revenue Authority office and also the company located in the city of Dessie. In particular, this research was limited to organizations involved in the manufacture, trade, service business while micro business organizations were not included in the object of this research. Data on CSR expenditure and Disclosure of CSR reports were obtained from the companies identified. This research was limited to a three-year period from 2015 to 2017 to evaluate financial performance using financial statements and also to identify the number of CSR activities to prepare CSR scores. In addition, this study was limited to four variables such as asset returns, capital intensity; Efficiency and CSR score to measure the influence of corporate social responsibility activities on the financial performance of selected business organizations.

According to the data obtained from Dessie town revenue office, there are 949 business organizations have been registered as category - A tax payers. Stratified random sampling was used to select sample business organizations from the population. In addition, purposive sampling was used to get the respondents from trade and industry office of Dessie town because informants were selected intentionally/purposefully to obtain the required data. Along with Cochran, (1977) statistical model, the appropriate sample size used for this study at $93 \%$ of level of significance with marginal error $7 \%$ was determined. As a result, 142 samples were taken out of 949 business organizations for this study. The total population was stratified as manufacturing, merchandized and service under category A tax payment. Then, from each stratum proportional samples were randomly selected by applying proportional sampling technique. The Table 1 shown the proportion of sample size used from each firm type and category of tax payment. 
Efficacy of Social Accounting Practices... (Uvaneswaran, Zemen, Muhammed)

Table 1. Total number of population and sample size in each stratum

\begin{tabular}{lcc}
\hline \multirow{2}{*}{ Nature of Industries } & \multicolumn{2}{c}{ Category A } \\
\cline { 2 - 3 } & No. of firms & Sample size \\
\hline Merchandise & 585 & 87 \\
Manufacturing & 25 & 4 \\
Service & 339 & 51 \\
Total & $\mathbf{9 4 9}$ & $\mathbf{1 4 2}$ \\
\hline
\end{tabular}

To realize the target, the owner or manager of the company and government officials from the Dessie City trade and industry office became the primary data source and information was collected through a questionnaire. Secondary data was collected from the company's annual report. Content analysis was used to determine CSR scores based on the number of sentences dedicated to each component of CSR in the company's annual report. Quantitative data were then analyzed using the Statistical Package for Social Sciences (SPSS) 27 tool Version 20.0. The Multiple Linear Regression Model was used to test the significant relationship between CSR practices reported in annual financial statements and financial performance. The relationship is explained by the following regression model:

$$
\text { ROAt }=\alpha 0+\beta \text { CSR }_{t-1}+\beta 2 \mathrm{EFF}_{\mathrm{t}-1}+\beta 3 \mathrm{CI}_{\mathrm{t}-1}+\mathrm{e}
$$

Where ROA is Return on Assets; CSR is represent Corporate Social Responsibility; EFF is Efficiency; CI is Capital Intensity for firm; e is error term; $\alpha 0$ is Constant; and t- 1 is represent the previous period.

\section{Result and Discussion}

To achieve the research objectives, data are grouped into demographic factors, disclosure methods of CSR activities in the Reporting format and to study the effect of social accounting practices on financial performance.

\section{Respondents Profile}

Participatory respondent information regarding gender, age, and education status collected from manufacturing organizations, merchandising and services is shown as Table 2. It is indicated regarding to the gender of the respondents, the most business sector in Dessie town was owned by male participants. The age group of respondents who were running the business firms was relatively young and belongs to less than 20 Years of age. The majority of the entrepreneurs or Business owners were educated up to second grade.

Table 2. Demographic characteristics of the respondents

\begin{tabular}{|c|c|c|c|}
\hline Item & Category & Frequency & Percentage (\%) \\
\hline \multirow{3}{*}{ Gender } & Male & 95 & 66.9 \\
\hline & Female & 47 & 33.1 \\
\hline & Total & 142 & 100 \\
\hline \multirow{4}{*}{ Age } & Below 20 Years & 56 & 39.4 \\
\hline & 21-30 Years & 54 & 38.0 \\
\hline & $31-40$ years & 32 & 22.5 \\
\hline & Total & 142 & 100 \\
\hline \multirow{4}{*}{ Educational Status } & Second Grade & 84 & 59.2 \\
\hline & Diploma & 56 & 39.4 \\
\hline & First Degree & 2 & 1.4 \\
\hline & Total & 142 & 100 \\
\hline
\end{tabular}

Social Accounting and Reporting Practices

In examining the responsibility of disclose of CSR and Environmental accounting in Financial Statements, Table 3 shown $79 \%$ of the respondents did not disclose information about CSR expenditure. In addition, $10 \%$ of the respondents were planning to disclose the information about CSR expenses in future whereas $11 \%$ of the respondents disclosed the information of CSR and Environmental activities in their 
company statements. This indicated that, most of the respondents did not disclose the CSR related expenses in their company financial statements to avail exemption from the income tax.

Table 3. Disclose of CSR and environmental accounting

\begin{tabular}{|c|c|}
\hline Disclose status (CSR) & Percentage (\%) \\
\hline Disclosed & 11 \\
\hline Not disclosed & 79 \\
\hline Plan to disclose & 10 \\
\hline Total & 100 \\
\hline
\end{tabular}

Table 4. Methods of disclosure of CSR and environmental accounting

\begin{tabular}{lc}
\hline \multicolumn{1}{c}{ Methods of CSR disclosure } & Percentage (\%) \\
\hline Standalone report & 29 \\
Corporate annual report & 50 \\
Directors report & 14 \\
Social responsibility report & 7 \\
Total & $\mathbf{1 0 0}$ \\
\hline
\end{tabular}

Table 5. Procedure to report the CSR activities

\begin{tabular}{lcc}
\hline \multicolumn{1}{c}{ Methods } & Frequency & Percentage (\%) \\
\hline Classical approach & 5 & 36 \\
Descriptive approach & 3 & 21 \\
Integral Theoretical approach & 0 & 0 \\
Socio economic operating statement & 6 & 44 \\
Socio income statement & 0 & 0 \\
Total & $\mathbf{1 4}$ & $\mathbf{1 0 0}$ \\
\hline
\end{tabular}

Table 6. Reasons for non-disclosures of CSR

\begin{tabular}{lccc}
\hline \multicolumn{1}{c}{ Statements } & Total & Frequency & Total (\%) \\
\hline No legal or similar regulatory requirement & 110 & 27 & 25 \\
Not required by the standards of the accounting standards & 110 & 38 & 34 \\
committee & 110 & 36 & 32 \\
Insufficient demand & 110 & 21 & 19 \\
Cost outweighs benefit & 110 & 29 & 27 \\
Information is sensitive and confidential & 112 & 16 & 14 \\
Would like to, but unsure how to proceed & 112 & 16 & 14 \\
Management does not appreciate its social responsibility & 112 & 11 & 10 \\
The objectives of the company emphasize its economic & & \\
rather than social performance & & \\
\hline
\end{tabular}

From Table 4, only 50\% of the respondents disclosed CSR activities in Annual reports, 29\% showed as standalone report, $14 \%$ of them showed through director's statements and the remaining $7 \%$ of the respondents showed their CSR expenses in Social responsibility report as per GRI. This table indicated that the half of business organization from the total of 14 respondents disclosed their CSR accounting through Corporate Annual Reports.

It is shown from Table 5, about 14 respondents followed certain procedure to prepare CSR report from the total of 16 respondents. Accordingly, 36\% of the respondents prepared CSR reports by following classical approach, where as $21 \%$ of them followed descriptive approach and $44 \%$ of the respondents followed socio economic operating statement method to prepare CSR reports. This indicated that the majority of the companies followed the procedure of Socio Economic Operating Statement to show their CSR activities.

From Table 6, about the reasons for non-disclosure of CSR activities in the Financial statements from the total of 110 respondents, about $34 \%$ of the respondents stated that not required by the standards of the accounting standards committee, where as $32 \%$ respondents represented as insufficient demand and $25 \%$ of respondents expressed the reasons as no legal or similar regulatory requirements as reasons for nondisclose of CSR. Following that, $27 \%$ of them replied as that the information is sensitive and confidential and $19 \%$ of them as cost outweigh benefits. On the other hand, out of 112 respondents expressed the reasons for non-disclosure of CSR that nearly $14 \%$ of them due to unsure how to proceed and Management does not appreciate its social responsibility and at the same time that $10 \%$ of the respondents expressed the 
reasons for non- disclosure of CSR as objectives of the company emphasis its economic rather than social performance. Thus it can be concluded that the organization did not disclose information about CSR due to non-requirement by the standards of the accounting standards committee.

\section{Social Accounting Disclosures}

This study used content analysis to measure social accounting disclosures and its effect on financial performance of companies in Dessie Town. This method was chosen due to its ability to analyze different types of communication tools including those in written code. Content analysis was used to examine written materials contained in the annual reports. This type of analysis was used due to the fact that this study only focused on two documents, which is the annual report and financial report submitted by the companies to the Dessie revenue authority office. The targeted population for the research was 142 companies. These are the total number of companies and among these companies 14 business organizations were involved in Manufacturing, Merchandising and Service render business are disclosing their Corporate Social activities in the financial statements. For consistency of information 142 required for the research, only 14 companies were analyzed. The financial statements of the companies relating to the accounting period from 2015 to 2017 G.C are taken to analyze the financial performance and accounting information of CSR activities. The reason for selecting this accounting period was data availability from the Dessie revenue authority office and also latest accounting period.

Table 7. Result of descriptive statistics

\begin{tabular}{lcccc}
\hline \multicolumn{1}{c}{ Variables } & ROA & EFF & CI & CSR \\
\hline Number of observations & 14 & 14 & 14 & 14 \\
Mean & 0.364707 & 0.861021 & 0.249650 & 7.3571 \\
Median & 0.357550 & 0.829350 & 0.144300 & 6.0000 \\
Std. Deviation & 0.2428373 & 0.1895045 & 0.2734888 & 4.86126 \\
Minimum & 0.0691 & 0.6377 & 0.0745 & 1.00 \\
Maximum & 0.7823 & 1.3903 & 1.1157 & 18.00 \\
\hline
\end{tabular}

According to Table 7, all variables comprised 14 observations and the profitability measure used in this study namely; ROA indicated that the business organizations attained, on average, a positive before tax profit over the 3 years. For the total sample, the mean of ROA was $36.4 \%$ with a minimum of $6.9 \%$ and a maximum of $78.23 \%$. This meant that from the selected business organizations the most profitable companies earned $78.23 \%$ of profit before tax for a one birr invested in the firm's asset. Conversely, the least profitable Companies from the selected Companies got $6.9 \%$ of profit before tax for a single birr invested in the firm's assets. The standard deviation statistics for ROA was (0.242) which indicated that the profitability variations between the selected companies were large. The result implied that these Companies needed to optimize the use of their assets to increase the return on their assets.

Managerial efficiency had the mean value of 0.861021, with the maximum value of 1.3903 and minimum value of 0.6377 which showed the highest variability, the standard deviation value of 0.1895 which was the highest variability as compared to other CI variable. The mean value indicated that companies were not efficient because their operating expense per unit of operating return was high, which meant for 0.861021 birr operating expense there was one birr operating income. The average value of Company CI was 0.249650 , and the range of maximum values was 1.1157 to a minimum value of 0.0745 which was a high variability among variables. The value of the standard deviation variable was 0.2734888 , moderate deviation compared to other explanatory variables. The average value of Capital Intensity indicated that a business organization did not invest money to produce one birr of sales revenue.

On the other hand, CSR Score was measured by content analysis to identify the number of Social Responsibility activities carried out by the selected company. The CSR of the company chosen in this study had an average value of 7.3571, and the maximum and minimum values were 18.00 and 1.00 . The standard deviation value was 4.86126 which was the highest value among the independent variables. These results indicated that selected companies have more variation in their CSR activities.

\section{Analysis of Variance}

Multiple linear regressions are the most common form of the regression analysis. As a predictive analysis, multiple linear regressions are used to describe data and to explain the relationship between one dependent variable and two or more independent variables. The variables used in the study were Efficiency (EFF), Capital Intensity (CI) and CSR Score (CSR). The variables mentioned are used in regression analysis to determine the impact on Return on Assets (ROA). 
Table 8 shown that the $\mathrm{F}$ value is statistically significant at $P=0.149: P<0.05$ when the variables are entered. The model explains the relationship between the independent variables and the dependent variable. Moreover, this model is significant and this means that the independent variable explain the dependent variable.

Table 8. Significant difference between the variables - ANOVA

\begin{tabular}{|c|c|c|c|c|c|c|}
\hline & Model & Sum of Squares & df & Mean square & $\mathbf{F}$ & Sig \\
\hline \multirow{3}{*}{$\mathbf{a}$} & Regression & 0.306 & 3 & 0.102 & \multirow{3}{*}{2.218} & \multirow{3}{*}{$.149 \mathrm{~b}$} \\
\hline & Residual & 0.46 & 10 & 0.046 & & \\
\hline & Total & 0.767 & 13 & & & \\
\hline
\end{tabular}

\section{Regression Model}

$\mathrm{R}^{2}$ in regression was seen as a measure of model prediction ability during the sample period, or as a measure of how well the regression was estimated according to the data. R2 was the proportion of variation in the dependent variable explained by the regression model. The higher the value of $\mathrm{R} 2$, the greater the percentage variation of the dependent variable explained by regression, namely the better the goodness of fit for sample observations. On the other hand, a small R2 value indicated that the model did not match the data properly. The estimation results of the regression models used in this study were presented in Table 9. R-squared statistics and squared-R statistics adjusted for the model were $40 \%$ and $21.9 \%$. The results showed that changes in the independent variables explained $40 \%$ of changes in the dependent variable. That meant CSR scores; Efficiency and Capital Intensity collectively explained 40\% of changes in ROA. $60 \%$ of the remaining changes in ROA were explained by other variables not included in this model. As a result, these variables together were predictive variables of the profitability of business organizations. The F value of 0.149 indicated not statistically significant, meaning that changes in the independent variables had an effect on the dependent variable both positively and negatively.

Table 9. Estimation of standard error deviation - model summary

\begin{tabular}{cccccccccc}
\hline Model & $\mathbf{R}$ & $\begin{array}{c}\mathbf{R} \\
\text { Square }\end{array}$ & $\begin{array}{c}\text { Adjusted } \\
\text { R Square }\end{array}$ & $\begin{array}{c}\text { Std. Error } \\
\text { of the } \\
\text { Estimate }\end{array}$ & $\begin{array}{c}\mathbf{R} \\
\text { Square } \\
\text { Change }\end{array}$ & $\begin{array}{c}\text { F } \\
\text { Change }\end{array}$ & df1 & df2 & $\begin{array}{c}\text { Sig. F } \\
\text { Change }\end{array}$ \\
\hline 1 & $.632^{\mathrm{a}}$ & .400 & .219 & .2145487 & .400 & 2.218 & 3 & 10 & .149 \\
\hline a. Predictors: (Constant), CSR Score 1, Efficiency, Capital Intensity & & & & \\
\hline
\end{tabular}

Table 10. Regression coefficients

\begin{tabular}{|c|c|c|c|c|c|c|c|c|}
\hline & \multirow[t]{2}{*}{ Model } & \multicolumn{2}{|c|}{$\begin{array}{l}\text { Unstandardized } \\
\text { Coefficients }\end{array}$} & \multirow{2}{*}{$\begin{array}{c}\begin{array}{c}\text { Standardize } \\
\text { d } \\
\text { Coefficients }\end{array} \\
\text { Beta } \\
\end{array}$} & \multirow[t]{2}{*}{$\mathbf{t}$} & \multirow[t]{2}{*}{ Sig. } & \multicolumn{2}{|c|}{$\begin{array}{l}95.0 \% \text { Confidence Interval for } \\
\text { B }\end{array}$} \\
\hline & & B & Std. Error & & & & Lower Bound & Upper Bound \\
\hline \multirow{4}{*}{$\mathrm{a}$} & (Constant) & .780 & .290 & & 2.684 & .023 & .132 & 1.427 \\
\hline & Efficiency & -.446 & .402 & -.348 & -1.109 & .293 & -1.341 & .450 \\
\hline & Capital Intensity & -.324 & .280 & -.365 & -1.157 & .274 & -.949 & .300 \\
\hline & CSR Score 1 & .007 & .014 & .136 & 477 & .644 & -.025 & .039 \\
\hline
\end{tabular}

a. Dependent Variable: Return on Assets

Table 9 also shown that the coefficient of capital intensity and Efficiency against ROA are negative as far as the coefficients for those variables are negative $(-0.446)$ and $(-0.324)$. This point outs that there is a negative relationship between the above mentioned four independent variables and ROA. Hence the decrease of those factors will direct to an increase in ROA.

On the other hand, CSR score variables have a positive relationship with profitability as far as their respective coefficient is 0.007 . This revealed that there was a direct relationship between the CSR and ROA. In general as per the regression results provided among the three independent variables are used in this study, from Table 10 the regression equation was established as follows:

$$
\mathrm{Y}=0.780+0.007 \mathrm{CSR}_{\mathrm{t}-1}+(-0.324) \mathrm{EFF}_{\mathrm{t}-1}+(-0.446) \mathrm{CI}_{\mathrm{t}-1}+0.290
$$


The regression equation, it was determined that when CSR scores, company efficiency and capital intensity were zero, financial performance would be 0.781 . An increase in units in CSR scores would cause an increase in financial performance by a factor of 0.007 while a decrease in the unit of capital intensity would cause an increase in financial performance by a factor of 0.324 and a decrease in units in efficiency would cause an increase in financial performance by a factor of 0.446 . Therefore, there was a positive effect or relationship with CSR scores that measured Corporate Social Accounting and Financial Performance from business organizations selected in the study area. Regarding the gender of the respondent, most business sectors in the city of Dessie were owned by men. The age group of respondents who run a business company was relatively young and belonged to a group of less than 20 years. The majority of entrepreneurs or business owners were educated to second grade.

In examining the disclosure responsibilities of CSR and Environmental accounting in the Financial Statements, most respondents did not disclose CSR related expenses in their company's financial statements to obtain exemption from income tax. Therefore, the Ministry of Finance and Economic Development (MOFED) and educational institutions joined together to provide training to Public Accountants about the importance of CSR contributions and their benefits in relation to tax reduction for companies and also to create awareness among various business companies through the development service community. In terms of Corporate Social Responsibility \& Environmental Accounting disclosure method, it was revealed that half of the business organizations out of a total of 14 respondents described their CSR accounting through the Company's Annual Report and also followed the Ethiopian Commercial code for reporting accounts relating to CSR and the environment. At the same time, this reporting format was different from the social statement approach (SSA) compared to the Kathikeyan (2013) study because SSA contained information about the income statement and balance sheet.

The organization did not disclose information about CSR because there was no standard requirement by the accounting standard committee. Therefore, MOFED and the Ethiopian Commercial Code might form strict norms for companies to contribute to CSR activities based on the scale of operations that would definitely bring the country to improving economic and social conditions and also provide information that the total CSR contribution is fully exempt from tax according IFRS and GRI. Multiple linear regression was adopted to test the effect of CSR accounting and reporting practices on the financial performance of a particular company. From the regression equation it can be concluded that, when CSR scores, company efficiency and capital intensity were zero, financial performance would be 0.781 , it meant that the increase in units in CSR scores would cause an increase in financial performance by a factor of 0.007. While the decrease in units in the intensity of capital would cause an increase in financial performance by a factor of 0.324 and a decrease in units in efficiency would cause an increase in financial performance by a factor of 0.446 . Therefore, there was a positive effect or relationship with CSR scores that measured Corporate Social Accounting and Financial Performance from business organizations selected in the study area. These findings were evidence from the study of Cochran (1984) and Oduol (2009) that there was a positive relationship between accounting and social reporting with the environment and the company's financial performance.

The results of this study are slightly different when compared with Jerotich (2013) study that CSR practices, capital efficiency and intensity have a positive effect on the company's financial performance, but this study only has a relationship with the practice of CSR and Return on Assets. However, studies conducted by Margolis et al. (2002) support this study that there are mixed effects on short-term and longterm financial impacts when compared with the relationship between corporate social responsibility and corporate financial performance. Extreme contradictions occur in agribusiness companies in Bangladesh, while CSR; return on assets (ROA) \& earnings per share (EPS) does not have a significant impact on financial performance (Resmi, Begum, \& Hassan, 2018).

The CSR program is an investment for companies for the growth and sustainability of the company and is no longer seen as a cost center, but rather as a profit center (Gallego-Álvarez, Prado-Lorenzo, \& García-Sánchez, 2011; Vogel, 2012). The CSR program is the company's commitment to support the creation of sustainable development. On the other hand, the public questioned whether companies that are oriented towards maximizing economic benefits have a moral commitment to distribute the benefits of building local communities, because over time people not only ask companies to provide goods and services needed, but also require social responsibility (D. Dhaliwal, Li, Tsang, \& Yang, 2014; D. S. Dhaliwal, Radhakrishnan, Tsang, \& Yang, 2012). The implementation of CSR programs is one form of implementation of Good Corporate Governance. Good Corporate Governance is needed so that the behavior of business people has a direction that can be referred to by regulating the relationship of the interests of all stakeholders that can be met proportionally, preventing significant mistakes in the company's strategy, and ensuring that errors can be corrected immediately. In this case it needs to be emphasized that CSR is 
different from charity or social contribution (Crisóstomo, De Souza Freire, \& De Vasconcellos, 2011; Zhu \& Zhang, 2015).

CSR must be carried out in a program by taking into account the long-term needs and sustainability of the program. While social contributions are more temporary and have temporary impacts. The spirit of CSR is expected to help create a balance between the company, society and the environment (Bondy \& Starkey, 2014; Wu et al., 2015). Basically, CSR is expected to be a culture for Ethiopian people in particular, and the world community in togetherness in an effort to overcome social and environmental problems. Based on the discussion described, it can be concluded if CSR as a measure of Corporate Social Accounting cannot improve financial performance, it is necessary to suspect CSR that has not been implemented in accordance with the target market (Huang \& Watson, 2015; Wan Ahamed, Almsafir, \& Al-Smadi, 2014).

\section{Conclusions, suggestions and limitations}

Most of business organizations in the city of Dessie adhere to social accounting reporting even though they follow the Ethiopian Commercial code rather than the Global Imaging Reporting (GRI) as a temporary reporting guide and most reports are non-monetary forms and some companies use socioeconomic operating statements. Further studies found that there was a positive relationship between CSR scores measuring social accounting practices and the negative relationship between capital efficiency and intensity and the financial performance of selected business organizations for the period reviewed 20152017. This study observes that an increase in corporate social responsibility scores will lead to an increase in the company's financial performance; owners and top-level officials from business organizations must study or practice accounting and social and environmental reporting because it will enhance the company's reputation by improving financial performance in particular and overall will lead to economic growth and prosperity of the nation.

\section{References}

Aguilera, R. V., D. E. Rupp, C. A. Williams and J. Ganapathi. (2007). Putting the S back into corporate social responsibility: A multilevel theory of social change in Organizations, Academy of Management Review, 32(3), 836-863

Bondy, K., \& Starkey, K. (2014). The dilemmas of internationalization: Corporate social responsibility in the multinational corporation. British Journal of Management. https://doi.org/10.1111/j.14678551.2012 .00840

Chepkoech, Z. M., Chenuos, N. K., \& Kosgei, D. K. (2015). Green procurement strategies as determinants of financial performance: evidence from small and medium enterprises in Uasin-Gishu County, Kenya. International Journal of Small Business and Entrepreneurship Research, 3(2), 1-15

Cochran PL (1984), Corporate social responsibility and financial performance. Academy Journal of Management, 27(1), 42-56

Crisóstomo, V. L., De Souza Freire, F., \& De Vasconcellos, F. C. (2011). Corporate social responsibility, firm value and financial performance in Brazil. Social Responsibility Journal. https://doi.org/10.1108/17471111111141549

Crowther, D. (2000). Social and environmental accounting. London: Financial Times Prentice Hall

Daniel F. Ofori, Richard B. Nyuur, Mildred D. S-Darko (2014). Corporate social responsibility and financial performance: Fact or fiction? a look at Ghanaian banks. available at http://www.actacommercii.co.za/index.php/acta/article/download/180/255 retrieved on 8/05/18

Deegan, C. \& Rankin, M. (1996).Do Australian companies report environmental news objectively? an analysis of environmental disclosures by firms prosecuted successfully by the Environmental Protection Authority. Accounting, Auditing \& Accountability Journal, 9(2), 50-67

Dhaliwal, D., Li, O. Z., Tsang, A., \& Yang, Y. G. (2014). Corporate social responsibility disclosure and the cost of equity capital: The roles of stakeholder orientation and financial transparency. Journal of Accounting and Public Policy. https://doi.org/10.1016/j.jaccpubpol.2014.04.006

Dhaliwal, D. S., Radhakrishnan, S., Tsang, A., \& Yang, Y. G. (2012). Nonfinancial disclosure and analyst forecast accuracy: International evidence on corporate social responsibility disclosure. Accounting Review, https://doi.org/10.2308/accr-10218

Dowling, J. \& Pfeffer, J. (1975). Organizational legitimacy: social values and organizational behaviour. Pacific Sociological Review, January: 122-136

Du, S., Bhattacharya, C. B., \& Sen, S. (2010). Maximizing business returns to corporate social responsibility (CSR): The role of CSR communication. International Journal of Management 
Reviews. https://doi.org/10.1111/j.1468-2370.2009.00276.x

Friedman, M. (1970). The social responsibility of business is to increase its profits, NY Times Magazine

Farah Naz ,Farrukh Ijaz and Faizan Naqvi (2016), Financial performance of firms: evidence from Pakistan Cement Industry, Journal of Teaching and Education, 05(01), 81-94. https://papers.ssrn.com/sol3/papers.cfm?abstract_id=2788357

Gallego-Álvarez, I., Prado-Lorenzo, J. M., \& García-Sánchez, I. M. (2011). Corporate social responsibility and innovation: a resource-based theory. Management Decision. https://doi.org/10.1108/00251741111183843

Global Reporting Initiative (GRI), (2006). Sustainability reporting guidelines. Draft version for Public comment, GRI, Amsterdam 2 January 2006-31 March 2006.

Gray, R. H. (2000). Current developments and trends is social environmental auditing and attestation. International Journal of Auditing, 4, 247-268

Huang, X. B., \& Watson, L. (2015). Corporate social responsibility research in accounting. Journal of Accounting Literature. https://doi.org/10.1016/j.acclit.2015.03.001

Iyoha F.O and D. Oyerinde (2010). Accounting infrastructure and accountability in the management of public expenditure in developing countries: a focus on Nigeria, Critical perspectives on Accounting 21 (5), 361-373

Jerotich OJ. (2013). The relationship between corporate social responsibility practices and financial performance of firms in the manufacturing, construction and allied sector of the Nairobi securities exchange, International Journal of Business, Humanities and Technology, 3(2):81-90

Kalunda, E. (2007). Corporate social reporting practices: the case of companies listed on the Nairobi stock exchange. Unpublished MBA Project, School of Business, University of Nairobi

M. Karthikeyan. (2013). Social statement approach to cooperative cocial performance assessment: a case of lume adama farmers cooperative union in Ethiopia. In 4th EMES International Research Conference on Social Enterprise. Institute of Cooperatives \& Development Studies, Ambo University

Margolis, J. D., Elfenbein, H. A., \& Walsh, J. P. (2002). Does it pay to be good? A meta-analysis and redirection of research on the relationship between corporate social and financial performance. Paper presentation at the Academy of Management Meetings, Philadelphia, PA

Maunders, K. (1982), Social reporting and the employment report, in Tonkin, D.J. and Skerratt, L. C. L. (eds) Financial Reporting 1981-1982, London: ICAEW

McWilliams, A., \& Siegel, D. S. (2011). Creating and capturing value: strategic corporate social responsibility, resource-based theory, and sustainable competitive advantage. Journal of Management. https://doi.org/10.1177/0149206310385696

Mills, D. L.; Gardner, M. J. (1984) Financial profiles and the disclosure of expenditures for socially responsible purposes. Journal of Business Research, v. 12, n. 4, p. 407-424

Oduol, F. O (2009) A survey of the social accounting and reporting practices adopted by the mobile service providers in Kenya. Unpublished MBA project, School of Business, University of Nairobi. Okeyo, W. O. (2004). A survey of levels and determinants of CSR among commercial firms in Kenya. Unpublished MBA project, School of Business, University of Nairobi

Porter, M E \& Krammer, M.R. (2006). Strategy \& society. Harvard Business Review, 82 (12), 78-92

Pricewaterhouse coopers (2002). Value reporting forecast: Bringing information out into the open. PWC Reports

Resmi, S. I., Begum, N. N., \& Hassan, M. M. (2018). Impact of CSR on firm's financial performance: a study on some selected agribusiness industries of Bangladesh. American Journal of Economics, Finance and Management, 4(3), 74-85. Retrieved from http://www.aiscience.org/journal/paperInfo/ajefm?paperId=4055

Saeidi, S. P., Sofian, S., Saeidi, P., Saeidi, S. P., \& Saaeidi, S. A. (2015). How does corporate social responsibility contribute to firm financial performance? The mediating role of competitive advantage, reputation, and customer satisfaction. Journal of Business Research. https://doi.org/10.1016/j.jbusres.2014.06.024

Torres, A., Bijmolt, T. H. A., Tribó, J. A., \& Verhoef, P. (2012). Generating global brand equity through corporate social responsibility to key stakeholders. International Journal of Research in Marketing. https://doi.org/10.1016/j.ijresmar.2011.10.002

Vogel, D. J. (2012). Is there a market for virtue? the business case for corporate social responsibility. California Management Review, https://doi.org/10.2307/41166315

Wan Ahamed, W. S., Almsafir, M. K., \& Al-Smadi, A. W. (2014). Does corporate social responsibility lead to improve in firm financial performance? evidence from Malaysia. International Journal of 
Economics and Finance. https://doi.org/10.5539/ijef.v6n3p126

Wu, L., Subramanian, N., Abdulrahman, M. D., Liu, C., Lai, K. hung, \& Pawar, K. S. (2015). The impact of integrated practices of lean, green, and social management systems on firm sustainability performance-evidence from Chinese fashion auto-parts suppliers. Sustainability (Switzerland). https://doi.org/10.3390/su7043838

Zhu, Q., \& Zhang, Q. (2015). Evaluating practices and drivers of corporate social responsibility: the Chinese context. Journal of Cleaner Production. https://doi.org/10.1016/j.jclepro.2015.03.053 
